\title{
Gliére, Erdely, and the Harp in Russia
}

\author{
Ruth Mertens ${ }^{1 *}$
}

\begin{abstract}
Little is known about why Reinhold Gliére, a prominent Russian composer, chose to write two pieces for harp. Nevertheless, Gliére's Harp Concerto in E-Flat Major and Impromptu effectively use the harp's capabilities and have become standards in harp repertoire over the past century. The purpose of this study is to find out why Reinhold Gliére chose to write for the harp. This essay discusses the place of the harp in the 19th century, particularly in Russia. A brief biography of Gliére and his colleague, harpist Ksenia Erdely, is also provided, as well as a comparison of Gliére's two harp compositions with other contemporary pieces. The main questions that this study seeks to answer are where Gliére and Erdely met, why they worked together, and to what extent they collaborated. Likely answers are drawn from the two composers' educations and backgrounds as well as from an analysis of the compositional style and similarities of the two harp solos. Also included is a summary of important information that has not been obtained, in addition to ways that further research can continue providing insight into Gliére and his relationship with the harp.
\end{abstract}

\section{Keywords}

Reinhold Gliére — Ksenia Erdely — Harp Concerti

${ }^{1}$ College of Music, Music Performance, University of North Texas

${ }^{\star}$ Faculty Mentor: Dr. Jaymee Haefner

\section{Contents}

\section{Introduction}

1 The Development of the Harp in Russia

2 Gliére

3 Erdely

4 Analysis of Harp Compositions

5 Influences and Reasons

6 Conclusion

Author Biography

\section{Introduction}

Every harp concerto seems to have a fascinating origin story. People who are familiar with harp history know that Mozart was commissioned to write a flute and harp concerto by a wealthy aristocrat who wanted to perform on his flute with his harpist daughter. Mozart was never paid for his services, however, and he bitterly refused to write for the harp ever again. The story of Claude Debussy and Maurice Ravel is perhaps even more interesting, for not only were the two men rival composers, but they both wrote iconic harp concertos to be premiered by competing harp manufacturers. Debussy's Danse sacrée et danse profane was written for the express purpose of showing off the capabilities of the new chromatique harp designed by Gustave Lyon of Pleyel Co., while Ravel's Introduction et Allegro incorporated all of the expressive, chromatic capabilities of the double-action pedal harp created by Érard at the beginning of the 19th century.
The harp is such a complex instrument, and its history is so unique, that there are always stories about why certain composers wrote for the harp. These stories not only help inform harpists of the way they should perform the pieces, but also give musicians a greater appreciation and understanding of the significance of each piece. Consequently, I believe it is important to know why Reinhold Gliére, a prominent Russian composer from the Romantic era, chose to write not only a harp concerto, but also a tone poem for solo harp. These two pieces have become standards in harp repertoire due to their effective use of the harp's capabilities, as well as their lyricism and beauty.

Why was Gliére so good at writing for the harp, and why did he choose to write two solo pieces for such a unique and often neglected instrument? Composers in Russia, a country that was so often cut off from the Western world, had only begun incorporating the harp into their pieces about fifty years before Gliére began writing music. In this paper, I will discuss the place of the harp in Russia before and during Gliére's lifetime, in addition to looking at Gliére's musical background and the influence that harpist Ksenia Erdely had on Russian harpists and Gliére. I believe that all three of these subjects - the history of the harp in Russia, Gliére's musical heritage, and Erdely's friendship with Gliére-all influenced Gliére in his decision to write for the solo harp.

\section{The Development of the Harp in Russia}

The harp had a presence in Russia longer than most other instruments, similar to other countries around the world. How- 
ever, like in other countries, the Russian harp did not really come into its own until the early nineteenth century with the development of the double-action pedal harp. For centuries, harp makers had searched for a way to give the harp full chromatic abilities without doubling or tripling the number of strings. In 1810, Paris-based instrument maker Sébastien Érard introduced a harp that was both sturdier than its predecessor as well as featured pedals at its base that allowed for full chromaticism. ${ }^{1}$ With his new design, Érard revolutionized the harp world.

For many years, European harpists obtained their doubleaction pedal harps from France. This included most Russian harpists. ${ }^{2}$ The Russian style of playing, however, was greatly influenced by two German harpists, Wilhelm Posse (18521926) and Albert Zabel (1834-1910), who taught a number of Russian students who went on to establish the Russian method of playing. ${ }^{3}$ Zabel in particular had great influence on harp playing in Russia. Though he was a native of Berlin, Zabel spent much of his life in the royal court of St. Petersburg as a teacher at the conservatory there. ${ }^{4}$ Nevertheless, even though Zabel was a chief influence on the Russian style of playing, Russian harpists took what he and Posse taught them and developed their own unique way of playing. This was more out of necessity than of choice; Russia was relatively isolated from the rest of the world and Russian harpists had little opportunity to collaborate with European and American harpists. ${ }^{5}$

Something that harpists everywhere had in common was the fact that the double-action pedal harp ushered in the age of the orchestral harp. Before the nineteenth century, few composers had included the harp in their writings because of its limited capabilities, delicate nature, and small sound. As musicians realized what the double-action harp had to offer, however, more and more European composers began incorporating the harp into their music. Nikolai Rimsky-Korsakov was the first major Russian composer to write extensive harp parts in his works, and ultimately wrote more for the orchestral harp than any other Russian composer. ${ }^{6}$ Although RimskyKorsakov became most well known outside of Russia for his vivid operas and program music, he was also an extremely influential teacher. He taught at the St. Petersburg Conservatory and many of his students went on to become famous in their own right. Some of Rimsky-Korsakov's students followed his path and became teachers, such as Mikhail Ippolitov-Ivanov,

\footnotetext{
${ }^{1}$ Rosalind Rensch, Harps and Harpists (Bloomington, IN: Indiana University Press, 2007), 149.

${ }^{2}$ Iraida Poberezhnaya, "Life and Work of Ksenia Erdely (1878-1971), Professor of Moscow Conservatory," (PhD Lecture-Recital paper, Peabody Conservatory of the Johns Hopkins University, 2002), 16.

3 ibid., 6 .

${ }^{4}$ Hans Joachin Zingel, Harp Music in the Nineteenth Century, trans. and ed. by Mark Palkovic (Bloomington, IN: Indiana University Press, 1992), 46.

${ }^{5}$ Aristid von Wurtzler ,"The Harp Cult behind the Iron Curtain," Music Journal 21.2 (Feb 1, 1963): 62, 83.

${ }^{6}$ Natalia, Shameyeva, The Development of Harp Music in Russia XXth Century (Moscow, Russia: Tichenor, 1994), 7.
}

who wrote a number of pieces for solo harp ${ }^{7}$ and also taught Gliére.

The harp continued to gain prominence in Russian orchestral works over the course of the nineteenth century, but remained virtually unheard of as a solo instrument on the concert stage. ${ }^{8}$ This raises an interesting question: why did Gliére choose to write two solo pieces for such a neglected instrument, Concerto for Harp and Orchestra in E-Flat Major, Op. 74, and Impromptu?

\section{Gliére}

Reinhold Gliére was born on January 11, 1875, in Kiev, Ukraine. ${ }^{9}$ Gliére was of Belgian-Jewish heritage and grew up in a musical household. Even though his father was a woodwind maker, Gliere studied the violin. ${ }^{10}$ At the age of seventeen he began working with Czech violinist E. A. Ryb at the Russian Music School in Kiev. ${ }^{11}$ He went on to pursue music more seriously at the Moscow Conservatory in 1894. He studied composition with a number of different teachers, including Mikhail Ippolitov-Ivanov. Upon graduation, Gliére received a gold medal to recognize his outstanding work in composition. Nevertheless, when his first symphony received less than favorable reviews, Gliére chose to spend even more time studying composition, this time in Germany. ${ }^{12}$

Gliére's first composition that gained international attention was Symphony No. 3, Ilya Murometz, a piece that was inspired by a Russian folk story. ${ }^{13}$ Indeed, Russian folk tales and music became an important element in all of Gliére's future works. In addition, after the rise of the Soviet regime, Gliére was one of the first Soviet composers dedicated to preserving the folk music of the outlying Soviet Republics. ${ }^{14}$ Part of his drive was from his training in Moscow, where teachers like Ippolitov-Ivanov and Stepan Smolenskii had nurtured Gliére's interest in the folk music of Russia and its surrounding countries and republics. ${ }^{15}$

After graduating, Gliére taught private lessons and composition at the Kiev Conservatory. However, upon the retirement of Ippolitov-Ivanov in 1920, Gliére was appointed to the composition faculty at the Moscow Conservatory. ${ }^{16}$ Gliére remained in Russia for the rest of his life, teaching and composing. He was also involved in Soviet music organizations, and served as the head of the Moscow Union of Soviet Composers in 1937. Unlike other Russian composers such

\footnotetext{
${ }^{7}$ ibid, 8.

8 ibid, 7.

${ }^{9}$ Gregory A. Halbe, "An Historical Assessment of the Concerto of Reinhold M. Gliére (1875-1956)" (MM thesis, University of Kansas, 1986), 1.

${ }^{10}$ Elsa Z. Posell, Russian Composers (Boston, U.S.A.: Houghton Mifflin Company, 1967), 131.

${ }^{11}$ Halbe, "An Historical Assessment," 1.

${ }^{12}$ ibid, 4.

${ }^{13}$ David Ewen, 20th Century Music (Englewood Cliffs, New Jersey: Prentice-Hall, Inc., 1963), 145.

${ }^{14}$ Posell, Russian Composers, 130.

${ }^{15}$ Halbe, "An Historical Assessment," 4.

${ }^{16}$ ibid, 7 .
} 
as Shostokovich and Prokofiev, Gliére managed to stay in the favor of the Soviet regime, due to his established reputation and amiable nature. ${ }^{17}$

Gliére primarily composed incidental music for operas, plays, and ballets. However, during the years between 1939 and 1951, Gliére composed four concerti that greatly influenced Soviet music. ${ }^{18}$ A good example of Gliére's influence was the way that he wrote the third and final movement of his harp concerto: in a "brave" style that is reminiscent of a simple dance. This kind of final movement in a concerto became a standard of Soviet composers, with the exception of Shostakovich. ${ }^{19}$ That Gliére was essentially able to write the music he wished, in the style he wished, and even create Soviet music norms, speaks to his influence in the musical world. While most Soviet composers had to follow the rules laid out for them, Gliére was able to create music that was acceptable to his government by "pereklyuchenie na Sovetskuyu tematiku"- writing Soviet subject matter. ${ }^{20}$ In other words, Gliére continued to write in his majestic Russian manner, but applied his use of technique and orchestral color to Soviet themes. Perhaps the most famous example of this is his ballet The Red Poppy, premiered in 1927, which is full of Soviet propaganda but still is vibrant with musical color and dances. $^{21}$

Due to his popularity in the Soviet Union, Gliére's works were performed by numerous orchestras. Because he wrote most for the stage, however, it appears that Gliére's works were most frequently premiered by the Bolshoi Theatre Orchestra in Moscow, where harpist Ksenia Erdely performed for many years. ${ }^{22}$ Gliére likely met Erdely while working on his ballet Krasnii Mak in 1927, ${ }^{23}$ although it is possible that they became acquainted while teaching at the Moscow Conservatory. Erdely noticed that Gliére had an innate sense for writing harp music and urged him to write a concerto for her instrument. Ultimately the two musicians collaborated on the Harp Concerto in E-Flat Major. Although Gliére is listed as the concerto's composer, before the work was premiered Gliére graciously offered to make Erdely a co-author. ${ }^{24}$ She declined and was simply listed as an editor, but her own vast knowledge of writing for the harp and her love of Russian folk melodies shine through the entire concerto.

\footnotetext{
${ }^{17}$ ibid, 1.

${ }^{18}$ Stanley D. Krebs, Soviet Composers and the Development of Soviet Music.(W.W. Norton \& Company, Inc., New York), 75.

${ }^{19}$ ibid, 76.

${ }^{20}$ Nicolas Slonimsky, "Soviet Music and Musicians," Slavonic and East European Review. American Series 3, no. 4 (1944): 8.

${ }^{21}$ Ewen, 20th Century Music, 146.

${ }^{22}$ Phuttaraksa Kamnirdratana, "Reinhold Gliere's Concerto for Harp and Orchestra in E-Flat Major Op. 74: An Analysis and Performance Guide," $\mathrm{PhD}$ dissertation, University of Miami, 2012), 3.

${ }^{23}$ Halbe, "An Historical Assessment," 22.

${ }^{24}$ Kamnirdratana, "Reinhold Gliere's Concerto," 3.
}

\section{Erdely}

Like Gliére, Ksenia Erdely was originally from Ukraine. ${ }^{25}$ Born on February 20, 1878, into a wealthy family, Erdely did not study at either the Moscow or St. Petersburg conservatories like most of her contemporary Russian musicians. Instead, at the age of fifteen, Erdely began attending the Smolnyi Institute, a prestigious and unique school established under Catherine the Great. ${ }^{26}$ She received an excellent musical education and proved to be an accomplished pianist, choral singer, conductor, and harpist. ${ }^{27}$

Erdely's harp teacher at Smolnyi, renowned harpist and arranger Ekaterina Walter-Kühne, proved to be a source of comfort and wisdom for Erdely, who was far from home and unsure of what career she wished to pursue. Erdely and her harp playing were put in the spotlight very early on, including a performance for the Russian Emperor Alexander III. ${ }^{28}$ Not surprisingly, Erdely ultimately chose to become a professional harpist and Walter-Kühne helped her become the Assistant Principal Harpist in the Italian Opera Orchestra in St. Petersburg. ${ }^{29}$ Performing with this prestigious orchestra allowed Erdely to learn important harp parts, meet influential musicians, and work with a number of conductors. Thus, when she auditioned for a position in the Bolshoi Theatre Orchestra, Erdely was more than well prepared ${ }^{30}$ and held the position for thirty years.

Erdely's position as principal harpist with the Bolshoi Theatre Orchestra was possibly her first introduction to Gliére. The two musicians developed a long friendship and a mutual respect for one another. ${ }^{31}$ Erdely collaborated with Gliére at least once, but she was sought after by many other composers as well, including A. I. Kos-Anatolksy, and V. N. Tsibin. ${ }^{32}$ Indeed, Erdely was so renowned as a soloist and arranger for harp that many composers either dedicated pieces to her because of her help in editing the pieces, or they wrote specific pieces for her to perform. ${ }^{33}$

Part of Erdely's willingness to work with composers was because, as a teacher and Russian harpist, she found the repertoire for harp limiting. Erdely's first teaching position was as a replacement for her former teacher Walter-Kühne at the Smolnyi Institute, but in 1918 she accepted a position at the Moscow Conservatory. ${ }^{34}$ Resources were extremely limited for musicians after the October Revolution in 1917, but Erdely persevered in procuring harps and music for her students $\mathrm{s}^{35}$ and eventually became one of the most influential harp teach-

\footnotetext{
${ }^{25}$ Wenonah Milton Govea, Ninteenth- and Twentieth-Century Harpists, (Westport, CT: Greenwood Press, 1995), 84.

${ }^{26}$ Poberezhnaya, "Life and Work of Ksenia Erdely,7.

${ }^{27}$ Govea, Ninteenth- and Twentieth-Century Harpists, 10.

${ }^{28}$ Poberezhnaya, "Life and Work of Ksenia Erdely," 10.

${ }^{29}$ Kamnirdratana, "Reinhold Gliere's Concerto," 26.

${ }^{30}$ ibid, 27.

${ }^{31}$ ibid, 23.

${ }^{32}$ Shameyeva, The Development of Harp Music, 25.

${ }^{33}$ Poberezhnaya, "Life and Work of Ksenia Erdely," 13.

${ }^{34}$ Govea, Ninteenth- and Twentieth-Century Harpists, 88.

${ }^{35}$ ibid, 89.
} 
ers in Russia. Because one of her greatest frustrations in teaching was the harp's limited repertoire, her dedication to working with composers and even arranging older pieces for harp reveals Erdely's love of teaching and expanding the harp world.

Despite Erdely's great influence in Russia, for many years she was practically unheard of in the rest of the world. The reason for Erdely's lack of fame outside of Russia was because she was never a member of the Soviet regime. ${ }^{36}$ Both her brother and husband were sent away to Soviet concentration camps, but Erdely was inexplicably allowed to continue her teaching, performing, and composing in freedom. ${ }^{37}$ Fortunately, in more recent years harpists around the world have begun to study Erdely and perform her pieces.

\section{Analysis of Harp Compositions}

Because there are so few sources that directly list Gliére's reasons for writing for solo harp, one of the best ways to learn about his thinking is through analysis of the two pieces he wrote. In addition, since Erdely was so influential in writing at least the harp concerto, it is also important to see what her characteristic composition traits were and figure out how the two musicians combined forces. This will help explain to some extent the influences on Gliére when he wrote for the harp.

Gliére often incorporated the harp into his orchestral works, usually writing arpeggio accompaniment that supported the melodic line. While this concept is not really possible for a solo piece like Impromptu, where the harp is the only instrument that can play the melody, Gliére does use this method in the concerto. When the orchestra takes the melody, Gliére scored the harp part so that the soloist plays repeating arpeggios that ascend and descend, providing support and color to the orchestra. Gliére also liked to write passages of high rolled chords in his harp parts, another element that appears in both the harp concerto and Impromptu. Furthermore, the Impromptu bears similarities to Gliére's works for solo piano in that some of its passages contain a simple, emotional melody that is accompanied by constant arpeggios in the bass.

Melodically, both Gliére's harp concerto and Impromptu bear great resemblance to Russian folk tunes, which is unsurprising since both he and Erdely were passionate about preserving and incorporating traditional songs into their compositions. Unlike other Russian composers who used folk melodies in their compositions, such as Igor Stravinsky, Gliére and Erdely ensured that the melody was not broken up and was distinguishable from the rest of the piece. ${ }^{38}$

Gliére's harp concerto is written much like nineteenthcentury, Romantic concerti, in contrast to the pieces his Soviet contemporaries were turning out. As far as musical form is concerned, Gliére's composition is stylistically conservative

\footnotetext{
${ }^{36}$ Poberezhnaya, "Life and Work of Ksenia Erdely," 4.

37 ibid, 22.

${ }^{38}$ Poberezhnaya, "Life and Work of Ksenia Erdely," 37.
}

and very much in keeping with the precedent set by composers such as Anton Rubenstein. ${ }^{39}$ The concerto is written in typical concerto form, with three movements: the first, "Allegro Moderato," is in sonata form; the second, "Andante," is a theme and variations; and the final movement, "Allegro Giocoso" is once again in sonata form. ${ }^{40}$ However, despite Gliére's adherence to the form used by Western Russian composers, the harmonies and orchestration the Gliére employed are more in keeping with composers such as Rimsky-Korsakov and his student Alexander Glazunov. ${ }^{41}$

The harp concerto's structure is, at least at a surface level, similar to other works by Gliére. The first movement of the Harp Concerto in E-flat Major opens much like the first movement of Gliére's Horn Concerto, Op. 91. and his Concerto for Coloratura Soprano, Op. 82. In all three concerti the full orchestra begins the piece, falls back to allow the solo instrument to introduce the theme of the movement, and then the soloist and orchestra combine to develop the theme and move the piece forward.

Because it is often hard for the harp's voice to be heard above a full orchestra, Gliére downsized the number of instruments needed to near-chamber orchestra proportions. In addition, he often scored solo passages for the harp with little to no orchestral accompaniment. As a further method of helping the harp sound over the orchestra and still maintain the audience's interest, Gliére included a wide variety of textures in the harp part, including rolled chords, blocked chords, arpeggios, and glissandi. Without a doubt, this was the area where Erdely's assistance was the most valuable to Gliére.

Researchers such as Gregory Halbe have noted that the scoring of Gliére's harp concerto bears great resemblance to that of French composers Claude Debussy and Maurice Ravel. Although it is possible that Gliére researched these two composers' solo works for harp, it is far more likely that Erdely had studied these pieces before and told Gliére about them. Both of Gliére's solo works for harp feature the complex cross-rhythms between hands that Debussy and Ravel incorporated into their pieces, ${ }^{42}$ but Erdely's own compositions featured similar passages, ${ }^{43}$ and the concept is certainly one that harpists would be more familiar with than a composer.

Ultimately, it seems as though Gliére had the most control over the form and orchestration of the concerto, and Erdely wielded the most influence over the harp part itself. The solo incorporates many techniques that Erdely included in her personal compositions, such as long, lyrical melodic lines played by the right hand thumb with arpeggios surrounding them. ${ }^{44}$ This technique is featured extensively in the Gliére Impromptu, as well. Another similarity between the two Gliére compositions are the rolled chords featured at the opening of each piece, which is also very similar to the way Erdely began her

\footnotetext{
${ }^{39}$ Halbe, "An Historical Assessment," 12.

${ }^{40}$ ibid, 32-34.

41 ibid, 16-17.

${ }^{42}$ Halbe, "An Historical Assessment," 23.

${ }^{43}$ Kamnirdratana, "Reinhold Gliere's Concerto," 32

${ }^{44}$ ibid, 47.
} 
harp solo Ukraine. ${ }^{45}$ The chords span much of the harp and fit into harpists' hands, once again indicating Erdely's touch.

Even though Erdely appears to have worked primarily on the solo harp part for the concerto, she did influence the harmonies that Gliére included. Halbe notes that the "harmony throughout the concerto is remarkably tame for Gliére," and he believes this is because Erdely brought the issue of the harp pedals to Gliére's attention. ${ }^{46}$ The harp's pedals control the chromaticism of each string, and harpists can only change two pedals at a time. Thus, the more modulations and accidentals included in a piece, the harder the piece can become. Many composers are unaware of this difficulty, but Gliére's knowledge of the way the harp's pedals work is apparent throughout the composition, including in the second movement theme where he included a lot of chromaticism but managed to only have the harp move two pedals at a time. ${ }^{47}$

\section{Influences and Reasons}

Although I have been unable to come to any solid conclusions as to why Reinhold Gliére chose to write two solos for the harp, I have been able to reach some reasonable theories as to what influenced his decisions. First of all, he was well trained in the tradition of Nikolai Rimsky-Korsakov, who included harp parts in a majority of his compositions. Mikhail Ippolitov-Ivanov was one of Gliére's most influential mentors, and he, too, had written a number of works for the harp. Thus, it is not surprising that Gliére often chose to include harp in his compositions.

However, this does not fully explain why Gliére chose to write for solo harp, and it is unlikely that historians could know for certain Gliére's reasons without finding something he privately wrote about the harp. The pressure Ksenia Erdely put on Gliére certainly encouraged him to write his harp concerto, but it is possible that he wrote his Impromptu before meeting Erdely. This is hard to know with certainty, however, because very little is known about the background of Impromptu, including the year it was written. Historians have discovered, though, that Erdely used this tone poem as an encore piece when she toured Russia performing the harp concerto. ${ }^{48}$ Furthermore, a version of the music from the personal collection of Dr. Jaymee Haefner of the University of North Texas lists Erdely as an editor and was published sometime before 1995 in Russia. Is it possible that this term "editor" is used in the same way as in the harp concerto? Did Erdely collaborate with Gliére on writing Impromptu, or did she just go back and make few changes to a piece of music that he had written years before?

Based on my analysis of the two compositions, I think it is likely that Erdely also helped Gliére write Impromptu, perhaps even with the intent of it being the encore piece to the concerto. Gliére often wrote dramatic, grand pieces while

\footnotetext{
${ }^{45}$ Poberezhnaya, "Life and Work of Ksenia Erdely," 38.

${ }^{46}$ Halbe, "An Historical Assessment," 30.

${ }^{47}$ ibid, 30.

48 ibid, 22.
}

Erdely preferred to use the harp's eponymous arpeggios. Both composers incorporated Russian folksongs into their works. The Impromptu features all of these elements, including passages with melodic arpeggios and simple, lyrical melodies that hearken back to Russian folk songs. These elements in the Impromptu bear the mark of both composers, and also tie it closely to the virtuosic harp solo in the concerto.

\section{Conclusion}

Gliére once said, "Who knows the instrument better than the performer? It behooves us to pay attention to performers, and we must learn from them." My research indicates that Gliére listened to his own advice when writing his concerto and Impromptu for harp. Though there is still research to be done on Gliére, Erdely, and their work together, the stories behind Harp Concerto in E-Flat Major and Impromptu are nearly complete and are proving to be just as interesting as those of Debussy's Danse sacrée et danse profane and Ravel's Introduction et Allegro.

At some point in the early 20th century, Gliére and Erdely met through their work, either at the Moscow Conservatory or the Bolshoi Theatre Orchestra. They became friends and worked closely with one another on at least one solo for harp, each motivated to write for the harp because of personal reasons. Gliére often included harp accompaniment in his orchestral works and Erdely was eager to expand the repertoire that Russian harpists could perform. Together Gliére and Erdely were able to write an effective concerto for harp, incorporating their mutual love of folk melodies, as well as techniques and forms that they had used in previous compositions. Since then, the Harp Concerto in E-Flat Major has stood the test of time and become a standard for harpists worldwide. Gliére's dramatic Impromptu, which served as an encore piece to the concerto, has gained much recognition in the harp community as well, but even less is known about its creation and inspiration.

In order to continue putting the pieces of the puzzle together, music historians will need to gain further access to Gliére and Erdely's personal writings, in addition to discovering more about the origins of the Impromptu and the reason it took so long for the piece to be published in the United States. In particular, Erdely's autobiography The Harp in My Life would be an invaluable resource, but researchers would need to locate and then translate an edition of it. Even without these few missing elements, however, the story behind Harp Concerto in E-Flat Major and Impromptu is both captivating and inspiring. Gliére and Erdely's work together as musicians, composers, and friends is a testament to the success of collaborations between composers and performers, for today both the Harp Concerto in E-Flat Major and Impromptu are iconic harp solos that are well-loved by harpists and audiences around the world. 


\section{Author Biography}

Harpist Ruth Mertens is currently pursuing a Bachelor of Music Performance degree at the University of North Texas under the instruction of Dr. Jaymee Haefner. Ruth is passionate about sharing her love of music with other people and is an active teacher, writer, and performer. Over the past two years Ruth has had the opportunity to research various aspects of music history, place in multiple concerto competitions, perform at the 13th World Harp Congress in Hong Kong, play with a variety of chamber groups and large ensembles, and serve as a harp teacher in the UNT String Project. In the rare moments when she is not playing or talking about the harp, Ruth enjoys spending time with her friends and family, singing classical and Disney songs, and sewing her own wardrobe. For more information, please visit RuthMertens.com. 